DOI 10.31558/2519-2949.2019.3.3

УДК 323(439)"1990/1999"

ORCID ID: https://orcid.org/0000-0001-8280-7104

Бусленко В. В., Донецький національний університет імені Василя Стуса

\title{
КОНВЕРТАЦІЙНІ СТРАТЕГІЇ ВЛАДИ ТА ПОЛІТИЧНОЇ ОПОЗИЦЇ̈ В УГОРЩИНІ В 1990-их рр.
}

Вияснено специфіку взаємовідносин влади та політичної опозиції в Угорщині в контексті теорії конвертаиії суспільних капіталів. Особлива увага приділена етапу перезавантаження влади, що логічно мало б призвести до системних змін та поглиблення модернізаційних процесів.

Якісні характеристики, темпи і результати модернізації політичної системи в Угорщині у значній мірі визначалися тим, наскільки ефективно політичні партії скористалися конкурентними умовами для накопичення та конвертачї різних форм капіталів на початку трансформаційного періоду. Вже на етапі перших демократичних виборів вони змогли швидко заповнити вакуум політичного поля, а обрані стратегії виявилися успішними як для них, так і для демократизачії політичного режиму.

В основі взаємодії уряду та політичної опозииї в Угорщині лежсать раціональні мотиви, в основі яких доступ до владних ресурсів. Вибір конфронтаційної чи кооперачійної стратегії взаємодї залежав від прогнозованих трансакційних витрат сторін. Звуження демократичних прав і свобод як результат політичної діяльності провладних партій, стає перепоною для здорової конкурениії в якій зацікавлена насамперед опозииія.

Приклад Угорщини показує, ще імітачійна модернізаџія, демократизаџія та прискорена європеїзачія призводять до політичної значимості «розриву» як ресурсу для накопичення політичного капіталу провладними партіями та створення ними власної мережі клієнтелістських відносин. В результаті відбувається потрапляння країни до інституційної пастки з наслідком кризи демократії. Поєднання парламентської та позапарламентської діяльності опозиції дозволяє концептуалізувати «дефіщит демократії» в передвиборчих програмах та з приходом до влади «виправити» помилки попереднього уряду. Тому чергування партій при владі призводить в кінцевому рахунку до зміцнення деморатії.

Ключові слова: Угорщина, влада, політична опозичія, демократія, теорія конвертащії суспільних капіталів.

Відмінності між переходом до демократії та іiі консолідацією зумовили актуальність проблематики дослідження концептуальних перспектив функціонування політичних інституцій та побудови оптимальної моделі взаємодії між ними як гарантії змінення демократії. Щодо самої демократії, то в останні десятиліття головна тема змінилася і цю перемінну констатував К. Поппер: «сьогодні це не виправдання ідеї демократії за допомогою етичних, богословських, філософських побудов чи аргументів здорового глузду, а занепокоєність іiі хрупкістю і пошуки способів іiі укріплення [12, с. 26]. Політична історія дає багато прикладів, коли демократія, формально зберігаючись в якості певної системи інститутів та процедур, поступово не відповідає класичному іiі розумінню як «правління більшості». Натомість зростає т.зв. «дефіцит демократії», коли спадає рівень співучасті громадян і послаблюється значимість опозиції в прийнятті політичних рішень. Це призводить до того, що модернізація політичної системи в країнах 3 приблизно однаковою структурою політичного поля є різною. Особливої актуальності набуває аналіз стосунків між парламентською опозицією та урядом в країнах, які демонструють нелінійність переходу до консолідованої демократії. В якості case study виступає Угорщина.

Метою статті є з'ясування на прикладі Угорщини взаємовідносин між владою та опозицією в контексті теорії конвертації суспільних капіталів. Особлива увага приділена етапу перезавантаження влади, що логічно мало б призвести до системних змін та поглиблення модернізаційних процесів.

Взаємовідносини влади та опозиції ще не стали предметом досліджень як зарубіжних, так і вітчизняних науковців. Конвертаційні стратегії основних політичних акторів опосередковано

(C) Бусленко В. В., 2019 
розглядають М. Мело, К. Денізер, А. Гелб [10], К. Поппер [12]. Особливості формування соціального капіталу в Угорщині, як ресурсу політичних партій, досліджено в роботах А. Агх [4], М. Райзера, К. Хаерпфера, Т.Новотного [13].Теоретичні аспекти проблеми проаналізовано в роботах О. Сидорчук, М. Лесечко [2], Ю. Плотинського [3]. В статті ми спиралися на дослідження Фонду Бертельсманна [7], соціологічні опитування Світового банку [14; 15] , дані Угорського статистичного центру[6].

Трансформаційні процеси, які відбувалися в цій країні на початку 1990-их рр., змінили об'єктивну структуру політичного поля, посиливши політичну суб'єктність не лише провладних, але й опозиційних партій. Досягнуті в результаті круглого столу домовленості щодо подальшого функціонування демократичних інститутів одночасно визначили певні правила взаємодії між ними. Проте такий інститут кооперативної взаємодії мав тимчасовий характер і окреслив лише контури міжпартійної конкуренції, як інструменту розподілу та перерозподілу метакапіталу держави між основними політичними гравцями. Встановлені параметри мали екзогенний характер, а основною їх ціллю стало надання режиму ознак демократичності. Звідси подібними залишалися до періоду перших демократичних виборів і стратегії накопичення суспільних капіталів. Для опозиційних партій - це боротьба з комуністичним режимом, а для комуністичних структур - пристосування до нової політичної системи.

Під час переходу до демократії процес конвертації капіталів не попадає під один стандарт, так як накопичення в одному інституційному середовищі не означає автоматичне відтворення в іншому. Тому після перших демократичних виборів партії намагалися врахувати у своїх стратегіях нове співвідношення сил, інституційний дизайн а також тенденції посилення політичної конкуренції не лише між опонентами, але і всередині провладного та опозиційного таборів.

В період зміни режиму значним коливанням підлягали цілі, інтереси та цінності, що не могло позначитися на практиці накопичення соціального капіталу новоствореними партіями. Одним з його базових складових залишалися впливи, пов'язані з горизонтальними зв'язками між людьми, що $є$ потенційним внеском на макрорівні в формування соціальних сіток. На думку О. Сидорчук, «на відміну від культурного і людського капіталу, соціальний капітал не $\epsilon$ атрибутом окремого індивіда, його об'єктивовану структурну основу формують мережі соціальних зв'язків, які використовуються для накопичення інформації, економії ресурсів, формування репутації. На основі соціальних зв'язків складається інституціональна основа соціального капіталу - приналежність до певного соціального кола чи членство в групі» [2, с. 33].

За даними соціологічних досліджень «Світове опитування цінностей» (WVS), проведених в 1990 р. Європейським банком реконструкції та розвитку, серед формальних інститутів найбільшу довіру отримала церква (2,61 з 4 максимальних) [14]. Проте в 1995 р. вплив релігійних інституцій на формування мережі горизонтальних зв'язків послабився до позначки 2,35 [15]. Більшість угорців віддавала перевагу малим формальним групам. Важливість друзів в сфері реалізації громадянської участі позитивно оцінили $38,33 \%$ респондентів [13, с. 9]. Натомість участь в громадських організаціях залишалася низькою та неінтенсивною. В 1995 р. членами профспілок виявилося лише 8 \% опитаних. Відмітимо, що в 1992-1994 pр. простежувалася висока динаміка створення ГО. Сама ж їх структура не мала нічого спільного з групами тиску, аналітичними центрами або з суспільно-політичними організаціями, що значною мірою обумовлювалося істотною фінансовою підтримкою зі сторони держави та громадян. Переважна частина ГО в певних сферах дублювала державні функції, залучаючи кошти на соціальні чи благодійні цілі.

Характерно, що значна кількість політичних партій, які визначали якісні характеристики перехідного процесу в кінці 1980-их рр., вийшла з середовища легальних чи нелегальних ГО. Зокрема, Федерація молодих демократів (далі «Фідес») утворилася з незалежного експертного руху коледжу. В той же час Альянс вільних демократів (АВД) сформувалася в рамках організації «Мережа соціальних ініціатив». Проте політична інертність громадських організацій на початку 90-их рр. робила їх малоперспективними в якості соціального капіталу для створення нових політичних проектів. В другій половині 1990-их інтенсивність створення ГО помітно знизилась, а на політичному полі не з'явилося нових впливових партій.

В умовах низького рівня формування інститутів громадянського суспільства досить динамічно протікали процеси накопичення та конвертації суспільних капіталів на рівні групових та індивідуальних акторів. Перші демократичні вибори до Національних зборів Угорщини, які відбулися в березні 1990 р., принесли успіх Угорському демократичному форуму. За нього віддали голоси 42,75 \% виборців. До парламенту також увійшло 22 депутати від постопозиційної Фідес. 
Партії зробили ставку на символічному капіталі, акцентуючи увагу виборців на цінностях, ідеях, символах, протиставленні.

Прихід до влади постопозиції започаткував хвильову динаміку циркуляції політичних еліт та кардинально змінив політичний, економічний та соціокультурний контекст вибору політичними акторами стратегій накопичення та конвертації капіталів. Для провладних партій основна 3 них відображала специфіку трансформаційних соціумів і полягала у тісному взаємозв'язку між політичними та економічними полями. Задекларованою ціллю став перехід економіки на ринкові відносини, який передбачав приватизацію державної власності та розвиток приватного підприємництва, розширення та захист економічних прав та свобод громадян. Проте модернізація та демократизація ставили перед елітою певні дилеми щодо вибору оптимальної стратегії накопичення капіталів. Нестабільність економічного розвитку, постійна міжпартійна конкуренція, зміни структури політичного поля, змушували робити постійну корекцію цілей та засобів. Рух, який зупиняється у роздумах перед вибором шляху Ю. Лотман назвав точкою біфуркації [3, с. 204]. Для політичної еліти в залежності від ситуації з'являлася значна кількість реперних точок, які фіксували ризик зменшення дивідендів від політичних інвестицій. Демократія ж давала право вибору між накопиченням економічного капіталу шляхом впровадження ринкових відносин чи через активізацію тіньових схем та задіювання неформальних інституцій.

Не маючи власних бізнесових інтересів, уряд не здійснював приватизацію на благо «наближених кіл», що приваблювало іноземних інвесторів. За даними ООН та Світового банку в Угорщині в 1990-1996 рр. зафіксовано найвищий сумарний наплив прямих іноземних інвестицій на душу населення - 1256 дол. В Чехії даний показник становив 674, в Польщі - 351, в Словаччині 190 [5, с. 69]. Прямі іноземні інвестиції в економіку країни залишалися найвищими серед країн Центрально-Східної Свропи і в 1990-1994 рр. сягали сумарно близько 6,5 млн. дол.

В Угорщині в 1994 р. зафіксовано один з найбільших кумулятивних індексів економічної лібералізації 4,11*. В Польщі він становив 4,14, в Чехії відповідно 3,61, в Словаччині 3,47 [10, с. 405]. Імплементація реформ детермінувала накопичення економічного капіталу в середовищі провладних партій. Проте даний процес значно уповільнився в силу того, що в Угорщині, як і в Польщі та Чеській республіці, утворився «капіталізм без капіталістів». Відповідно, постопозиція та партійна номенклатура не стали власниками великого економічного капіталу.

Одночасно для провладних партій виникли загрози втрати домінуючих позицій у політичному полі. Однією з причин стало те, що накопичення та конвертація суспільного капіталу відбувалися в умовах зростаючого контрасту між формальною демократизацією та соціальною дезінтеграцією. Системні зміни в Угорщині були добре спланованим політичним і економічним проектом, який передбачав формальну демократизацію і приватизацію з чіткими «імпортними» перспективами. Однак його істотним недоліком виявилася слабка розробка соціальної складової. Вона базувалась на припущенні, що економічні та політичні процеси призведуть до створення сильного середнього класу, котрий стане головним суб' єктом усіх подальших трансформацій. Вважалося, що загострення соціальних проблем носило тимчасовий характер i пов'язувалося з перехідним періодом, а відновлення економіки мало б автоматично вирішити всі соціальні проблеми, сприяючи реінтеграції угорського суспільства.

Проте модернізаційні зусилля уряду не були настільки сильними та синхронними щоб охопити всю країну та забезпечити однорідність процесів. Державний соціалізм з його примусовою соціальною інтеграцією та плановою економікою сприяв згуртованості економічно активного населення в якому переважали працівники з низькою кваліфікацією. Соціальна згуртованість істотно послабилася в процесі приватизації-маркетизації так як значна частина низькокваліфікованих працівників в нових умовах не могла влаштуватися на роботу. Ці групи не повністю інтегрувалися в економічному та соціальному плані і залишилися поза межами ринку праці, що зазвичай компенсувалося схемами дострокового виходу на пенсію. Багатогранний процес маргіналізації низькокваліфікованих людей спричинив появу великого соціального класу 3 низькими доходами, який, на думку А. Агх охоплював третину населення [4, с. 7 ].

Започатковані модернізаційні процеси в економіці призвели до соціальної нерівності та росту безробіття. В 1996 р. воно становило 11,2 \% [6]. Найбільш постраждала від нього молодь віком 15-24 pр. За даними Світового банку в Угорщині ріст безробіття серед цієї категорії зріс з 17,97 \% в 1991 р. до 22,76 \% в 1993 р. В 1996 р. цей показник становив 19,25\%. Далі спостерігається поступове зниження пї рівня до 10,63 в 2001 р. [9]. Таким чином, процес інтеграції країни до міжнародної конкурентоспроможної економіки залишав за собою велику маргіналізовану групу, 
виключену не лише з результатів економічного зростання, але і з гідних умов життя. Впродовж першого десятиліття демократичного переходу, соціальне невдоволення загрожувало великим розчаруванням та песимізмом в соціальній конструкції демократії. Тому процеси економічної та соціальної ізоляції на початку 1990-их рр. поєднувалися в політичному вимірі 3 процесами демобілізації та кризою участі.

На цьому фоні в першій половині 90-их рр. відбувалися процеси акумулювання політичного капіталу в опозиційному таборі. Зокрема, колишня правляча партія Угорщини УСРП напередодні виборів на своєму з'їзді відмовилася від комуністичної ідеології та ревізіонувала в бік соціалдемократії, перетворившись на Угорську соціалістичну партію (УСП). Проте соціалістичні ідеї на той час ще не знайшли своїх прихильників. Партія на виборах 1990 р. отримала лише 8,55\% голосів виборців і разом з іншими лівими не увійшла до парламенту, перейшовши до опозиції. Вважається, що оптимальний відрізок часу, необхідний опозиційній партії для ідейно-політичної консолідації та реформування, на практиці не повинен перевищувати чотирьох-п'яти років. В іншому випадку виборець розглядатиме ії як неефективну та сумніватиметься в спроможності керувати країною. Характерно, що саме в цьому часовому діапазоні відбулося репозиціонування для більшості посткомуністичних партій. Зокрема, в 1994 р. соціалісти здобули абсолютну більшість голосів (54,6 \%), що дозволило їм сформувати фракцію чисельністю 209 депутатів. У порівняні 31990 р. рівень підтримки партії в 1994 р. зріс в три рази (з 10,89 \% до 32,99 \%) [1, с. 114].

Зміна партій при владі в 1994 р. демонструє циклічний характер політичного розвитку країни, коли виведена в результаті приходу до влади опозиції система, прийшла в стан рівноваги за рахунок статусного та економічного капіталу «модернізованої» соціалістичної партії. Такі форми капіталів накопичувалися ще до перехідного періоду за рахунок вдалої економічної політики реформованої компартії. Тому на фоні погіршення економічного становища громадян, спричиненого політикою постопозиції, відбулося перетікання економічного капіталу до соціалістів та конвертація в політичний як бонус за минулу ефективну економічну політику. Проте, через жорсткі заходи економії, здійснені кабінетом Д. Горна після 1995 р., виборці швидко втратили будь-які ілюзії, що соціалісти зможуть надати їм такий самий рівень соціального забезпечення, яким користувалися в «золотий вік» державного соціалізму в 1980-их рр.

У період 1989-1996 рр. в країні спостерігався спад економіки. Економічна криза призводила до зниження рівня легітимності владної еліти. Тому перебування в опозиції позитивно впливало на процес конвертації статусного капіталу партії в політичний. Таким становищем вдало скористалася Фідес, яка поступово почала займати нішу правого центру. Накопичення політичних та інших форм капіталів а також розмір прибутку у разі успішної реалізації конвертаційної стратегії, стимулювали Фідес впливати на уряд в межах певних встановлених інституційних рамок та процедур. Йдеться, насамперед, про імпічмент, інтерпеляції, критику дій уряду, діяльність в парламентських комісіях тощо. Проте урядова коаліція соціалістів-лібералів спиралася на парламентську більшість, яка нараховувала понад $2 / 3$ депутатів. Така чисельна перевага дозволяла їй вносити зміни до Основного закону та мінімізувати критичний потенціал опозиції.

У випадку ефективного розподілу податкових надходжень та прийняття популярних рішень політика уряду призвела б до зростання політичного капіталу провладних партій. Проте такий вид капіталу, за концепцією німецького дослідника Р. Мюнха включав також і кредитні політичні ресурси, які отримувала партія на демократичних виборах [11, с. 170]. Такі ресурси мають нестійкі характеристики і залежать від ефективності правлячих партій скористатися мегакапіталом держави. Критерієм можуть виступати ріст економіки, покращення соціальних стандартів, консолідація демократії тощо. Вони здатні, особливо під час виборів, динамізувати перетікання різних форм капіталів в політичний.

Парламентські вибори 1998 р. принесли успіх Фідес, яка утворила коаліцію з постопозиційними НПДВ і УДФ. Характерно, що партія намагалася долучити до сукупного суспільного капіталу капітал міжнародної підтримки. 3 цією ціллю впродовж 1992-2000 pp. вона входила до Ліберального Інтернаціоналу, а в 2001 р. приєдналася до Європейської народної партії. Це дозволило ій, з одного боку, збільшити свій статусний капітал за рахунок входження до впливових європейських політичних структур. 3 іншого боку, Фідес отримувала додатковий політичний капітал зі сторони впливових європейських політиків. 3 огляду на перспективи вступу країни до ЄС для неї зростали шанси на входження до Європейського парламенту.

Діяльність нового уряду характеризує тісний взаємозв'язок політики та економіки. Накопичення економічного капіталу здійснювалося на платформі національного етатизму i проявлялося 
в сприянні угорському бізнесу та дискримінації іноземних інвесторів при наданні державних контрактів. Такий «популістський економічний націоналізм» знайшов вияв у формі ренаціоналізації ряду компаній та банків. В результаті перерозподілу власності Postabank та Hungarian Development Bank повернуто під контроль держави. Політика уряду призвела до зменшення довіри до нього зі сторони інвесторів. Послаблення зовнішнього репутаційного капіталу компенсувалося нарощуванням політичного капіталу Фідес в середовищі угорського бізнесу. В умовах нестабільної економічної ситуації для бізнесменів залишалося важливим максимально ефективно провести процеси приватизації найбільш рентабельних основних фондів взамін на підтримку економічного курсу уряду.

В міжелекторальний період усі економічні та інституційні реформи уряду оцінювалися з метою інтеграції Угорщини в СС до середини 2001 р. Задля цього лідер Фідес В. Орбан скористався економічним капіталом попередньої влади (рівнем розвитку економіки) та продовжив здійснювати політику реформ, встановлюючи нові макроекономічні напрями та дотримуючись успішної антиінфляційної політики. Проте, задекларована стратегія реформування суспільства не завжди співпадала 3 конвертаційною стратегією, яку вона втілювала для реалізації власних планів. Адміністрація Фідес уповільнила реалізацію пакету «Бокрос»- програми стабілізації економіки, започаткованої попереднім соціально-демократичним урядом, яка передбачала значні скорочення витрат на соціальне забезпечення. У зв'язку з цим продовжено розбудову успадкованої системи соціального захисту, збережено страхування на випадок інвалідності та безробіття, соціальне забезпечення та державну програму для інвалідів. Уряд спрямовував зусилля для боротьби 3 бідністю, яка міцно закріпилася в сільській місцевості серед ромської меншини, впровадивши політику реабілітації та реінтеграції. В результаті В. Орбану вдалося знизити рівень безробіття з 9,5 \% в 1998 р. до 7,1 \% в 2002 р. Проте уповільнення реалізації програми стабілізації економіки призвело до росту дефіциту бюджету з 7,4 \% від ВНП в 1998 р. до 8,8\% в 2002 р. [8].

Фідес прагнув використати статусний адміністративний капітал для посилення клієнтеліських мереж на рівні інституцій місцевого самоврядування. Експерти фонду Бертельсманна, відзначаючи повільний ріст територіальної інституційної децентралізації, зафіксували тенденцію до призначення після 1998 р., на адміністративні посади переважно представників Незалежної партії дрібних власників та симпатиків Фідес [7, с. 3]. В такий спосіб партія намагалася закріпити домінуюче положення на загальнодержавному рівні. Цей приклад демонструє побудову взаємозв'язку всередині елітної групи на стратегіях сітьової взаємодії, що супроводжується ростом клієнтелістської мережі.

Впродовж 1998-2002 рр. коаліція на чолі з В. Орбаном здійснювала спроби «корекції» перехідного періоду в певних сферах. Фідес намагався посилити вагу в метакапіталі держави, збільшивши контроль над Центральним банком, наглядовими органами, судовою гілкою влади. Зокрема було обмежено фінансування Конституційного Суду. В цьому ж контексті варто розглядати спроби тиску уряду на пресу, який посилився після прийняття в 1996 р. нового закону про ЗМІ. Він зобов'язував здійснювати призначення до Опікунської ради для суспільних медіа з представників провладних та опозиційних партій. Не дивлячись на його демократичність, формування ради відбувалося виключно з прихильників Фідес, що призвело до надмірного представництва правлячих партій у громадському радіо і телебаченні. Якщо взяти до уваги, що три з п'яти національних телеканалів належали державі, то можна також говорити про певну політичну заангажованість ЗМI.

В. Орбан також намагався послабити контролюючі функції парламентської опозиції. 3 цією метою обмежувався час на парламентські дебати щодо ефективності урядової політики. Представники опозиційних партій поступово витіснялися з усіх важливих парламентських комітетів і не мали можливості брати участь у слідчих комісіях. Однак, такий адміністративний ресурс не міг стати капіталом в довгостроковій перспективі. Угорщина на той час досягла значного прогресу в політичній трансформації. Вона мала розгалужену систему стримувань та противаг. Демократичні інститути та процеси, засновані на верховенстві права, консолідувалися швидше, ніж у всіх інших посткомуністичних країнах Центральної та Східної Свропи. Тому навіть у період правління Фідес Конституційний суд продовжував діяти як сильний, незалежний орган і реалізовував правозахисні функції. Швидка консолідація демократичних інституцій, заснованих на верховенстві права, перешкодила В. Орбану реалізувати стратегію акумулювання капіталів для здійснення домінуючого впливу на метакапітал країни.

Таким чином, якісні характеристики, темпи і результати модернізації політичної системи в Угорщині у значній мірі визначалися тим, наскільки ефективно політичні партії скористалися 
конкурентними умовами для накопичення та конвертації різних форм капіталів на початку трансформаційного періоду. Вже на етапі перших демократичних виборів вони змогли швидко заповнити вакуум політичного поля, а обрані стратегії виявилися успішними як для них, так і для демократизації політичного режиму.

В основі взаємодії уряду та політичної опозиції в Угорщині лежать раціональні мотиви, в основі яких - доступ до владних ресурсів. Вибір конфронтаційної чи коопераційної стратегії взаємодії залежав від прогнозованих трансакційних витрат сторін. Звуження демократичних прав і свобод як результат політичної діяльності провладних партій, стає перепоною для здорової конкуренції в якій зацікавлена насамперед опозиція.

Приклад Угорщини показує, що імітаційна модернізація, демократизація та прискорена європеїзація призводять до політичної значимості «розриву» як ресурсу для накопичення політичного капіталу провладними партіями та створення ними власної мережі клієнтелістських відносин. В результаті відбувається потрапляння країни до інституційної пастки з наслідком кризи демократії в країні. Поєднання парламентської та позапарламентської діяльності опозиції дозволяє концептуалізувати «дефіцит демократії» в передвиборчих програмах та 3 приходом до влади «виправити» помилки попереднього уряду. Тому чергування партій при владі призводить в кінцевому рахунку до зміцнення деморатії.

Не сприяс демократизації і штучний характер поляризації партій по лінії «ліві-праві» та формування потужних двох блоків, які періодично змінюють один одного. Конкуренція між ними відбувається не на основі формування та реалізації альтернативної політики а має технологічний, штучний характер. Вони не відтворюють лінії розмежувань в суспільстві, а намагаються поляризувати електорат. Атрибутивність, не виконання опозицією ії функцій, встановлення правил політичної гри вигідних основним політичним гравцям звужує міжпартійну конкуренцію. Т.зв. «керована конкуренція» посилює дефіцит демократії і сприяє занепаду ролі опозиції в процесах демократизації.

\section{Примітка:}

*Кумулятивний індекс лібералізації складається з суми річних індексів лібералізації впродовж 1990-1994 рр. Максимальний його показник - 4,5.

\section{Бібліографічний список:}

1. Бусленко В. Ліві партії-наступниці в країнах Вишеградської групи: репозиціонування в умовах політичної конкуренції. Вісник Наџіонального технічного університету Украӥни «Київський політехнічний інститут». Політологія. Соціологія. Право. Київ, 2014. № 2 (22). С. 111-116.

2. Лесечко М., Сидорчук О. Соціальний капітал: теорія і практика : монографія. Львів: ЛРІДУ НАДУ, 2010. $220 \mathrm{c}$.

3. Плотинский Ю. Теоретические и эмпирические модели социальных процес сов : уч. пособие. Москва: Логос, 1998. 280 c.

4. Ágh A. The triple crisis in Hungary: The «Backsliding» of Hungarian Democracy after Twenty Years. Romanian Journal of Political Science. Vol. 13, No. 1. 2013. Summer. P. 25-51.

5. Grabbe H., Hughes K. Enlarging the EU eastwards. London: Royal Institute of International Affairs, 1998. 130 p.

6. Hungarian Central Statistical Office. URL: https://www.theglobaleconomy.com/ hungary/unemployment_rate_monthly/ (дата звернення: 06.08.2019).

7. Hungary Country Report. 2003 / BTI. URL: https://www.bti-project.org/

fileadmin/files/BTI/Downloads/Reports/2003/pdf/BTI_2003_Hungary.pdf (дата звернення: 06.08.2019).

8. Hungary Government budget deficit. URL: https://countryeconomy.com/deficit/ hungary?year=2004 (дата звернення: 06.08.2019).

9. Hungary: youth unemployment. / The World Bank. URL: https://www.theglobal economy.com (дата звернення: 06.08.2019).

10. Melo M., Denizer C., Gelb A. Patterns of Transition from Plan to Market. The World Bank Economic Review. 1996. Vol. 10, No. 3. P. 397-424. URL: http://www.urbanlab.org/articles/China/reform\%20era/de\%20Melo\%20et\% 20al\%201996\%20-\%20transition\%20from\%20 plan\%20to\%20market.pdf (дата звернення: 06.08.2019).

11. Münch R. Politische Macht als Medium der Kommunikation / Dynamik der Kommunikationsgesellschaft Suhrkamp. Frankfurt am Main: Suhrkamp, 2014. P. 168-184.

12. Popper K. The Open Society and its Enemies Revisited. Economist. 1988. April. P. 20-38.

13. Raiser M., Haerpfer C., Nowotny T., Wallace C. Social capital in transition: a first look at the evidence / European Bank for Reconstruction and Development. Working Paper. 2001. No. 61. 30 p.

14. World Values Survey. 1990. URL: http://www.worldvaluessurvey.org (дата звернення: 06.08.2019).

15. World Values Survey. 1995. URL: http://www.worldvaluessurvey.org/ WVSDocumentationWV3.jsp (дата звернення: 06.08.2019). 


\section{References:}

1. Buslenko V. Livi partiyi-nastupnyci v krayinax Vyshegrads'koyi grupy: repozycionuvannya $\mathrm{v}$ umovax politychnoyi konkurenciyi. Visnyk Nacional ’nogo texnichnogo universytetu Ukrayiny «Ky`yivs`ky`j politexnichnyj instytut». Politologiya. Sociologiya. Pravo. Ky'yiv, 2014. \# 2 (22). S. 111-116. $220 \mathrm{~s}$

2. Lesechko M., Sydorchuk O. Social'nyj kapital: teoriya i praktyka : monografiya. L'viv: LRIDU NADU, 2010.

3. Plotinskij Ju. Teoreticheskie i empiricheskie modeli social'nyh processov: uch. posobie. Moskva: Logos, 1998. $280 \mathrm{~s}$.

4. Ágh A. The triple crisis in Hungary: The «Backsliding» of Hungarian Democracy after Twenty Years. Romanian Journal of Political Science. Vol. 13, No. 1. 2013. Summer. P. 25-51. $130 \mathrm{p}$.

5. Grabbe H., Hughes K. Enlarging the EU eastwards. London: Royal Institute of International Affairs, 1998.

6. Hungarian Central Statistical Office. URL: https://www.theglobaleconomy.com/ hungary /unemployment_rate_monthly/ (дата звернення: 06.08.2019).

7. Hungary Country Report. 2003 / BTI. URL: https://www.bti-project.org/ fileadmin/files/BTI/Downloads/ Reports/2003/pdf/BTI_2003_Hungary.pdf (дата звернення: 06.08.2019).

8. Hungary Government budget deficit. URL: https://countryeconomy.com/deficit/ hungary?year=2004 (дата звернення: 06.08.2019).

9. Hungary: youth unemployment. / The World Bank. URL: https://www.theglobal economy.com (дата звернення: 06.08.2019).

10. Melo M., Denizer C., Gelb A. Patterns of Transition from Plan to Market. The World Bank Economic Review. 1996. Vol. 10, No. 3. P. 397-424. URL: http://www.urbanlab.org/ articles/China/reform\%20era/de\%20Melo\% 20et\%20al\%201996\%20-\%20transition\%20from\%20 plan\%20to\%20market.pdf (дата звернення: 06.08.2019).

11. Münch R. Politische Macht als Medium der Kommunikation / Dynamik der Kommunikationsgesellschaft Suhrkamp. Frankfurt am Main: Suhrkamp, 2014. P. 168-184.

12. Popper K. The Open Society and its Enemies Revisited. Economist. 1988. April. P. 20-38.

13. Raiser M., Haerpfer C., Nowotny T., Wallace C. Social capital in transition: a first look at the evidence / European Bank for Reconstruction and Development. Working Paper. 2001. No. 61. 30 p.

14. World Values Survey. 1990. URL: http://www.worldvaluessurvey.org (дата звернення: 06.08.2019).

15. World Values Survey. 1995. URL: http://www.worldvaluessurvey.org/ WVSDocumentationWV3.jsp (дата звернення: 06.08.2019).

\section{Buslenko $V . V$. Conversion strategies of the power and the political opposition in Hungary in the 1990s}

The paper clarifies the specificity of the interrelationship between the power and the political opposition in Hungary in the context of the theory of conversion of public capital. Particular attention has been paid to the power reloading stage, which logically should have led to systemic changes and deepening of modernization processes.

The qualitative features, rates, and results of the modernization of Hungarian political system were mainly determined by how effectively political parties used the competitive conditions in order to accumulate and convert various forms of capital at the beginning of the transformation period. Even at the stage of the first democratic elections, they were able to quickly fill up the vacuum existing in the political field, and the chosen strategies were successful both for them and for the democratization of the political regime.

Rational motives, based on access to power resources, are at the heart of the interaction between government and political opposition in Hungary. The choice of either a confrontational or cooperative engagement strategy depended on the parties' estimated transaction costs. Limitation of democratic rights and freedoms as a result of the political activity of the pro-government parties became a barrier to healthy competition in which the opposition was primarily interested.

The example of Hungary demonstrates that simulation modernization, democratization, and accelerated Europeanization trigger the political significance of the "gap» as a resource for the accumulation of political capital by pro-government parties and the creation of their own network of clientelist relations. Consequently, the country falls into an institutional trap which results in the crisis of democracy. The combination of parliamentary and non-parliamentary opposition gives us a possibility to conceptualize the "deficit of democracy» in election programs, and to "correct» the mistakes of the previous government after coming to power. That is why the alternation of parties in power ultimately leads to the consolidation of democracy.

Key words: Hungary, power, political opposition, democracy, theory of conversion of public capital. 